\title{
Suppression of TPA-induced tumor cell invasion by sulfuretin via inhibition of NF-kB-dependent MMP-9 expression
}

\author{
JEONG-MI KIM $^{6 *}$, EUN-MI NOH $^{1 *}$, KANG-BEOM KWON $^{6 *}$, JONG-SUK KIM $^{1}$, \\ YONG-OUK YOU ${ }^{7}$, JIN-KI HWANG ${ }^{1}$, BO-MI HWANG ${ }^{1}$, MIN SEUK KIM ${ }^{2}$, SEUNG-JIN LEE ${ }^{3}$, \\ SUNG-HOO JUNG ${ }^{4}$, HYUN-JO YOUN ${ }^{4}$, EUN-YONG CHUNG ${ }^{5}$ and YOUNG-RAE LEE ${ }^{6,7}$ \\ ${ }^{1}$ Department of Biochemistry, Institute of Medical Science, Chonbuk National University Medical School, \\ Jeonju 560-182; ${ }^{2}$ Laboratory of Oral Physiology, College of Dentistry, Wonkwang University, Iksan 570-749; \\ ${ }^{3}$ Department of Pharmacy, College of Pharmacy, Ewha Womans University, Seoul 120-808; ${ }^{4}$ Division of Breast, \\ Thyroid Surgery, Department of Surgery, Chonbuk National University Medical School, Jeonju 560-756; \\ ${ }^{5}$ Department of Anesthesiology and Pain Medicine, Bucheon St. Mary's Hospital, The Catholic University of Korea, \\ Bucheon 420-717; ${ }^{6}$ Center for Metabolic Function Regulation, Wonkwang University School of Medicine, Iksan 570-749; \\ ${ }^{7}$ Department of Oral Biochemistry, School of Dentistry, Wonkwang University, Iksan 570-749, Republic of Korea
}

Received October 9, 2012; Accepted November 26, 2012

DOI: $10.3892 / o r .2012 .2218$

\begin{abstract}
Cell invasion is required for neoplastic metastasis. Matrix metalloproteinase-9 (MMP-9), which degrades the extracellular matrix, is a major component in the process of cancer cell invasion. Sulfuretin is one of the major flavonoids isolated from Rhus verniciflua. Sulfuretin has been used to reduce oxidative stress, platelet aggregation, the inflammatory response and mutagenesis. However, the effect of sulfuretin on breast cancer metastasis is unknown. In this study, we investigated the inhibitory effect of sulfuretin on 12-O-tetradecanoylphorbol-13-acetate (TPA)-induced MMP-9 expression and cell invasion in MCF-7 cells. Sulfuretin inhibited TPA-induced transcriptional activation of nuclear factor- $\kappa \mathrm{B}(\mathrm{NF}-\kappa \mathrm{B})$. We demonstrated that sulfuretin mediated the inhibition of TPA-induced MMP-9 expression and that cell invasion in MCF-7 cells involved suppression of the NF- $\kappa \mathrm{B}$ pathway. Therefore, inhibiting MMP-9 expression by sulfuretin may have therapeutic potential for controlling breast cancer invasiveness.
\end{abstract}

Correspondence to: Professor Young-Rae Lee, Department of Oral Biochemistry, School of Dentistry, Wonkwang University, Iksan 570-749, Republic of Korea

E-mail:mindyr@wku.ac.kr

Dr Eun-Yong Chung, Department of Anesthesiology and Pain Medicine, Bucheon St. Mary's Hospital, The Catholic University of Korea, Bucheon 420-717, Republic of Korea

E-mail: anes36@catholic.ac.kr

*Contributed equally

Key words: sulfuretin, MMP-9, invasion, NF-кB, MCF-7

\section{Introduction}

Breast cancer is one of the leading causes of cancer-related death in women (1). Despite successful treatment of the primary malignancy, relapse and subsequent metastatic spread can still occur at distant sites in the body through the bloodstream or lymphatic channels, including bone, lung, liver, kidney, thyroid and brain (2). Invasion and metastasis are fundamental processes and are the major causes of morbidity and mortality in patients with breast cancer. These processes require degradation of the extracellular matrix (ECM), which provides biochemical and mechanical barriers to cancer cell movement (3). The ECM consists of type IV collagen, laminin, heparan sulfate proteoglycan, nidogen and fibronectin (4). Degradation of the ECM requires extracellular proteinases, of which the matrix metalloproteinases (MMPs) play a critical role in breast cancer. Among the MMP family, gelatinases A (72 kDa gelatinase, type IV collagenase, MMP-2) and B (92 kDa gelatinase, type IV collagenase, MMP-9) play critical roles in ECM degradation and cell migration, leading to tumor cell invasion in breast cancer $(4,5)$.

MMP-9 is a key enzyme for degrading type IV collagen, which is a major component of the basement membrane. Elevated MMP-9 levels are functionally linked to elevated metastatic potential in many types of tumors, including brain (6), prostate (7), bladder (8), and breast $(9,10)$. A variety of stimuli, including growth factors (e.g. fibroblast growth factor-2, epidermal growth factor and hepatocyte growth factor), cytokines (e.g., tumor necrosis factor- $\alpha$ ), oncogenes (e.g., Ras) and 12- $O$-tetradecanoylphorbol-13-acetate (TPA) are involved in metastasis (11-14). Among these stimulators, TPA is a well-known selective activator of protein kinase C (11) and stimulates MMP-9 synthesis and secretion during MCF-7 cell invasion $(9,10)$. Consequently, inhibiting MMP-9 expression and/or its upstream regulatory pathways is critical for treating malignant tumors, including breast carcinoma. NF- $\mathrm{kB}$ and 
AP-1 are transcription factors important in the regulation of MMP-9, as the MMP-9 gene promoter contains binding sites for both factors (15). Studies have shown that the mitogen-activated protein kinase (MAPK) signaling pathway is important for AP-1 activation, and that NF- $\kappa$ B activation requires $\mathrm{I}-\kappa \mathrm{B}$ kinase, ERK, JNK and p38 MAPK, depending on the cell type (14,16-18).

Sulfuretin is a major flavonoid isolated from the heartwood of Rhus verniciflua Stokes (RVS), which has been used to reduce oxidative stress (19), platelet aggregation (20), the inflammatory response (21) and mutagenesis (22). A recent study found that sulfuretin inhibits cytokine-induced $\beta$-cell damage and prevents streptozotocin-induced diabetes by suppressing the $\mathrm{NF}-\kappa \mathrm{B}$ pathway (23). Therefore, it was hypothesized that sulfuretin may have anticancer properties that inhibit cell invasion. In the present study, sulfuretin was evaluated for its potential activity against TPA-induced cell invasion and MMP-9 expression in MCF-7 cells, and the related molecular mechanisms were investigated. Our results demonstrated that sulfuretin suppresses TPA-induced MMP-9 expression by blocking $\mathrm{NF}-\kappa \mathrm{B}$ activation but not AP-1 activation.

\section{Materials and methods}

Cells and materials. MCF-7 cells were obtained from the American Type Culture Collection (Manassas, VA, USA). The cells were cultured in Dulbecco's modified Eagle's medium (DMEM) supplemented with $10 \%$ fetal bovine serum (FBS) and $1 \%$ antibiotics at $37^{\circ} \mathrm{C}$ in a $5 \% \mathrm{CO}_{2}$ incubator. Sulfuretin was purchased from Symrise $\mathrm{GmbH} \& \mathrm{Co}$. (Holzminden, Germany). TPA, 3-(4,5-dimethyl-thiazol-2-yl)-2,5-diphenyltetrazolium bromide (MTT) and anti- $\beta$-actin antibodies were obtained from Sigma (St. Louis, MO, USA). Antibodies for p38, p-p38, JNK, p-JNK, ERK and p-ERK were purchased from Cell Signaling Technology (Beverly, MA, USA). Antibodies for MMP-9, p50, p65, proliferating cell nuclear antigen (PCNA), and horseradish peroxidase (HRP)-conjugated IgG were purchased from Santa Cruz Biotechnology (Santa Cruz, CA, USA). $\alpha{ }^{-32} \mathrm{P}-\mathrm{dCTP}$ was obtained from Amersham (Buckinghamshire, UK). High glucose-containing DMEM, FBS, and phosphate-buffered saline (PBS) were obtained from Gibco-BRL (Gaithersburg, MD, USA).

Determination of cell viability. The effect of sulfuretin on MCF-7 cell viability was determined using an established MTT assay. Briefly, $3 \times 10^{4}$ cells were seeded in wells and incubated at $37^{\circ} \mathrm{C}$ for $24 \mathrm{~h}$ to allow attachment. The attached cells were untreated or treated with $1,5,10,30$, and $50 \mu \mathrm{M}$ sulfuretin for $24 \mathrm{~h}$ at $37^{\circ} \mathrm{C}$. The cells were washed with PBS prior to adding MTT $(0.5 \mathrm{mg} / \mathrm{ml} \mathrm{PBS})$ and incubated at $37^{\circ} \mathrm{C}$ for $30 \mathrm{~min}$. Formazan crystals were dissolved with dimethyl sulfoxide (100 $\mu \mathrm{l} /$ well) and detected at $570 \mathrm{~nm}$ using a Model 3550 microplate reader (Bio-Rad, Richmond, CA, USA).

Western blot analysis. MCF-7 cells $\left(5 \times 10^{5}\right)$ were pretreated with 10 and $30 \mu \mathrm{M}$ sulfuretin for $1 \mathrm{~h}$ and then incubated with TPA for $24 \mathrm{~h}$ at $37^{\circ} \mathrm{C}$. Cells were lysed with ice-cold M-PER ${ }^{\circledR}$ Mammalian Protein Extraction reagent (Pierce Biotechnology, Rockford, IL, USA), and the protein concentration in the lysate was determined using the Bradford method (24).
Samples $(20 \mu \mathrm{g})$ were separated by sodium dodecyl sulfatepolyacrylamide gel electrophoresis with $10 \%$ acrylamide and transferred to Hybond ${ }^{\mathrm{TM}}$ polyvinylidene fluoride membranes (GE Healthcare Life Sciences, Buckinghamshire, UK) using a western blot apparatus. Each membrane was blocked for $2 \mathrm{~h}$ with $2 \%$ bovine serum albumin or $5 \%$ skim milk and then incubated overnight at $4^{\circ} \mathrm{C}$ with $1 \mu \mathrm{g} / \mathrm{ml}$ of a 1:2000 dilution of primary antibody. HRP-conjugated IgG (1:2000 dilution) was used as the secondary antibody. Protein expression levels were determined by signal analysis using an image analyzer (Fuji-Film, Tokyo, Japan).

Gelatin zymography assay. Conditioned media were collected after a $24 \mathrm{~h}$ stimulation, mixed with non-reducing sample buffer, and electrophoresed on a polyacrylamide gel containing $0.1 \%(\mathrm{w} / \mathrm{v})$ gelatin. The gel was washed at room temperature for 30 min with $2.5 \%$ Triton $\mathrm{X}-100$ solution, and subsequently incubated at $37^{\circ} \mathrm{C}$ for $16 \mathrm{~h}$ in $5 \mathrm{mM} \mathrm{CaCl}, 0.02 \%$ Brij and $50 \mathrm{mM}$ Tris- $\mathrm{HCl}$ ( $\mathrm{pH} 7.5)$. The gel was stained for $30 \mathrm{~min}$ with $0.25 \%$ (w/v) Coomassie Brilliant Blue in $40 \%$ (v/v) methanol/7\% (v/v) acetic acid and photographed using an image analyzer (FujiFilm). Proteolysis was imaged as the white zone in a dark blue field. Densitometric analysis was performed using Multi Gauge Image Analysis software (Fuji-Film).

Quantitative real-time polymerase chain reaction (PCR). Total RNA was extracted from cells using a FastPure ${ }^{\mathrm{TM}}$ RNA kit (Takara, Shiga, Japan). The RNA concentration and purity were determined by absorbance at 260/280 $\mathrm{nm}$. cDNA was synthesized from $1 \mu \mathrm{g}$ total RNA using a PrimeScript ${ }^{\mathrm{TM}}$ RT Reagent kit (Takara). MMP-9 and glyceraldehyde 3-phosphate dehydrogenase (GAPDH) mRNA expression was determined by real-time PCR using the ABI PRISM 7900 Sequence Detection system and SYBR ${ }^{\circledR}$ Green (Applied Biosystems, Foster City, CA, USA). The primers were: MMP-9 (NM 004994) sense, CCTGGAGACCTGAGAACCAATCT; antisense, CCACCC GAGTGTAACCATAGC and GAPDH (NM 002046) sense, ATGGAAATCCCATCACCATCTT; antisense, CGCCCCAC TTGATTTTGG. All results were normalized to the GAPDH housekeeping gene to control for variation in mRNA concentrations. Relative quantification was performed using the comparative $\Delta \Delta \mathrm{C}_{\mathrm{T}}$ method according to the manufacturer's instructions.

Preparation of the nuclear extract. MCF-7 cells $\left(2 \times 10^{6}\right)$ were treated with sulfuretin in the presence or absence of TPA for $4 \mathrm{~h}$. Cells were immediately washed twice, scraped into $1.5 \mathrm{ml}$ of ice-cold PBS ( $\mathrm{pH} \mathrm{7.5),} \mathrm{and} \mathrm{pelleted} \mathrm{at} \mathrm{1,500} \mathrm{x} \mathrm{g} \mathrm{for} 3 \mathrm{~min}$. Cytoplasmic and nuclear extracts were prepared from the cells using the NE-PER ${ }^{\circledR}$ Nuclear and Cytoplasmic Extraction reagent (Pierce Biotechnology).

Electrophoretic mobility shift assay (EMSA). Activation of $\mathrm{NF}-\kappa \mathrm{B}$ and AP-1 was assessed with a gel mobility shift assay using nuclear extracts. An oligonucleotide containing the $\kappa$-chain ( $\kappa$ B, 5'-AGTTGAGGGGACTTTCCCAGGC-3') or AP-1 (5'-CGCTTGATGAGTCAGCCGGAA-3') binding sites was synthesized and used as a probe for the gel retardation assay. The two complementary strands were annealed and labeled with $\left[\alpha{ }^{32} \mathrm{P}\right] \mathrm{dCTP}$. Labeled oligonucleotides $(10,000 \mathrm{cpm})$, 
A

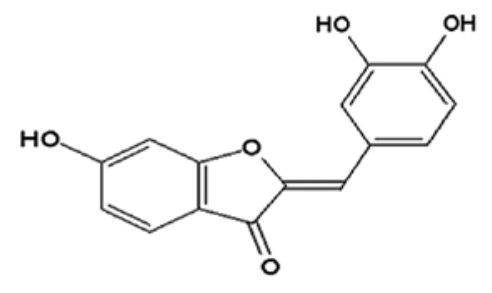

B

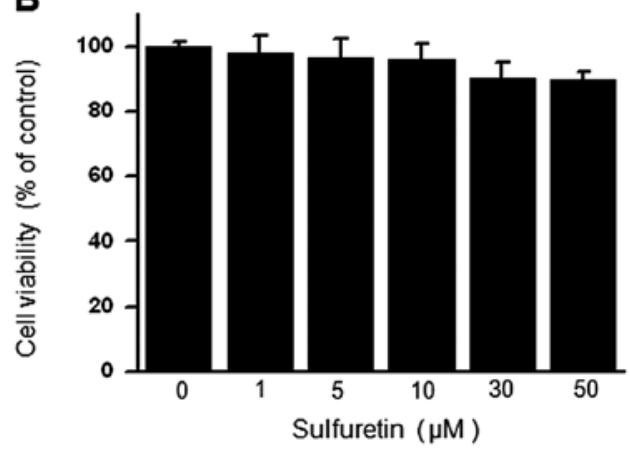

Figure 1. Effect of sulfuretin on MCF-7 cell viability. (A) The chemical structure of sulfuretin. (B) Assessment of the cytotoxic effect of sulfuretin on MCF-7 cells. Cells were cultured to $70 \%$ confluence in 96 -well plates, and various concentrations $(1,5,10,30,50 \mu \mathrm{M})$ of sulfuretin were added to the cells for 24 h. An established MTT assay was used to detect cell viability. The optical density value of the control was considered as $100 \%$. Each data point represents the mean \pm standard error of three independent experiments.

$10 \mu \mathrm{g}$ of nuclear extract and binding buffer $(10 \mathrm{mM}$ Tris- $\mathrm{HCl}$, $\mathrm{pH} 7.6,500 \mathrm{mM} \mathrm{KCl}, 10 \mathrm{mM}$ EDTA, $50 \%$ glycerol, $100 \mathrm{ng}$ poly $(\mathrm{dI} \cdot \mathrm{dC})$ and $1 \mathrm{mM}$ dithiothreitol) were then incubated for $30 \mathrm{~min}$ at room temperature in a final volume of $20 \mu \mathrm{l}$. The reaction mixtures were analyzed by electrophoresis on $4 \%$ polyacrylamide gels in $0.5 \mathrm{X}$ Tris-borate buffer. The gels were dried and examined by autoradiography. Specific binding was controlled by competition with a 50 -fold excess of cold $\kappa \mathrm{B}$ and AP-1 oligonucleotide.

Invasion assay. The invasion assay was carried out in 24-well chambers (8- $\mu \mathrm{m}$ pore size) coated with $20 \mu \mathrm{l}$ Matrigel-diluted DMEM. The Matrigel coating was rehydrated in $0.5 \mathrm{ml}$ DMEM for $30 \mathrm{~min}$ immediately before the experiments. Cells $\left(2 \times 10^{5}\right)$ were added to the upper chamber with chemoattractant in the bottom well. Conditioned medium $(0.5 \mathrm{ml})$ was added to the lower compartment of the invasion chamber, and the chambers were incubated for $24 \mathrm{~h}$. After the incubation, cells on the upper side of the chamber were removed using cotton swabs, and cells that had migrated were fixed and stained with toluidine blue solution. Invading cells were counted in five random areas of the membrane using a light microscope. Data are the means \pm standard errors from three individual experiments performed in triplicate.

Statistical analysis. The statistical analysis was performed using analysis of variance and Duncan's test. Differences with a $\mathrm{p}<0.05$ were considered statistically significant.

\section{Results}

Sulfuretin suppresses TPA-induced MMP-9 activation in $M C F-7$ cells. The chemical structure of sulfuretin is shown in Fig. 1A. To verify the effect of sulfuretin on cell viability, cells were seeded in 96-well culture plates at a density of $1 \times 10^{5}$ cells/well. The cytotoxic effect of sulfuretin on MCF-7 cells was analyzed using the MTT assay. Treatment of MCF-7 cells with the indicated concentrations of sulfuretin for $24 \mathrm{~h}$ did not result in any significant change in cell viability (Fig. 1B). Therefore, we performed the subsequent experiments using the optimal non-toxic concentrations $(10$ and $30 \mu \mathrm{M})$ of sulfuretin. Western blot analysis, real-time PCR and zymography were
A

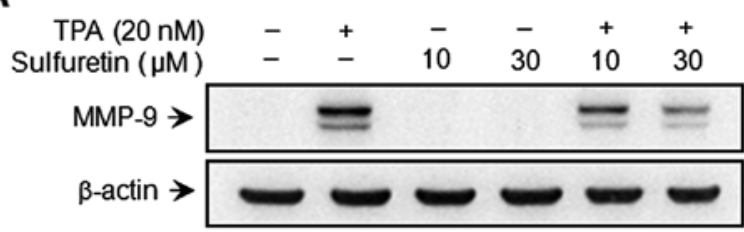

B

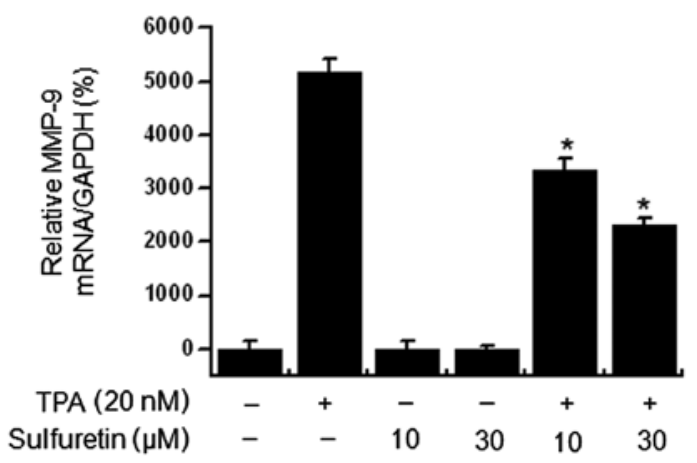

C

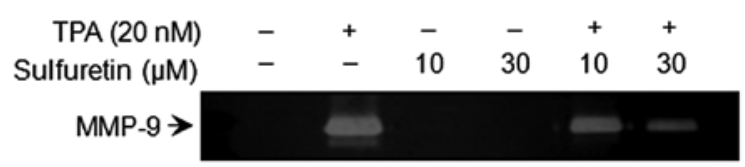

Figure 2. Sulfuretin inhibits TPA-induced MMP-9 expression in MCF-7 cells. MCF-7 cell monolayers were treated with the indicated concentrations of sulfuretin in the presence of TPA for $24 \mathrm{~h}$. (A) Cell lysates were analyzed by western blot analysis with the anti-MMP-9 antibody. The blot was reprobed with anti- $\beta$-actin to confirm equal loading. (B) MMP-9 mRNA levels were analyzed by real-time PCR, and GAPDH was used as an internal control. (C) Conditioned media were prepared and used for gelatin zymography. Each value represents the mean \pm standard error of three independent experiments. "p<0.01 vs. TPA.

performed in MCF-7 cell-containing samples to investigate the effect of sulfuretin on TPA-induced MMP-9 expression. The western blot analysis revealed that sulfuretin treatment of MCF-7 cells blocked upregulation of TPA-induced MMP-9 protein expression (Fig. 2A). Real-time PCR revealed a TPA-induced increase in the MMP-9 level in MCF-7 cells, and 

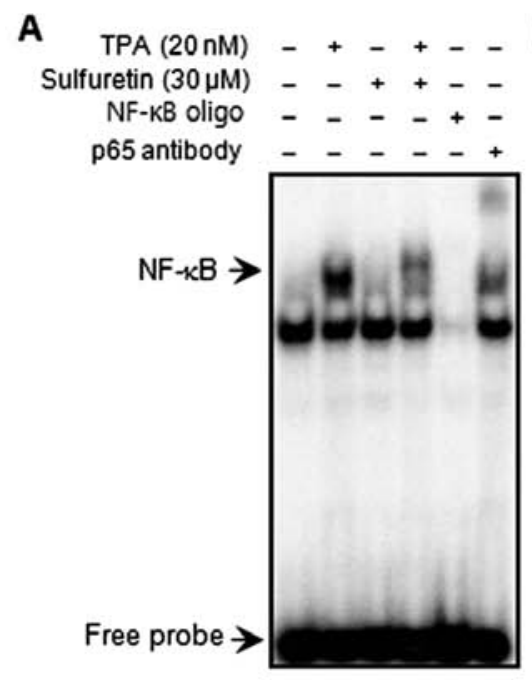

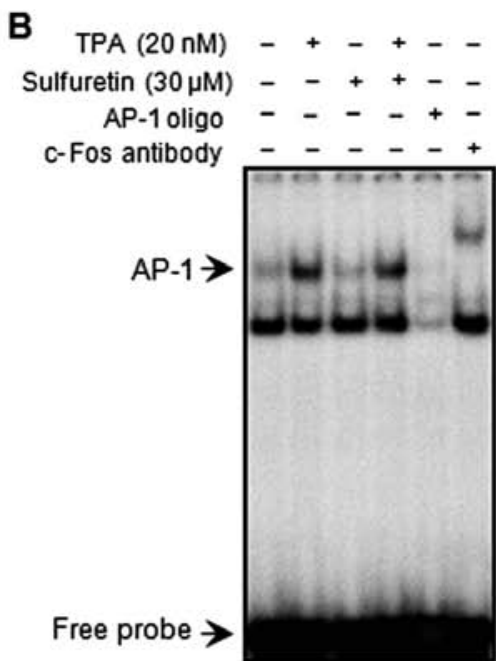

C

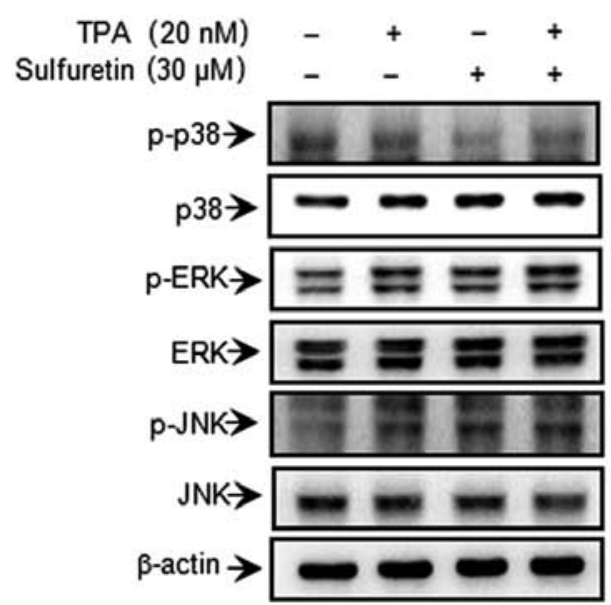

D

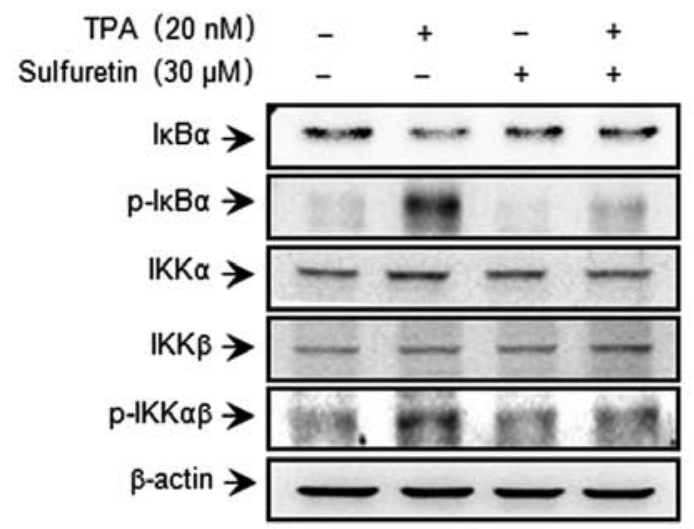

E



Figure 3. Sulfuretin inhibits TPA-induced NF- $\mathrm{KB}$ DNA binding activity but not AP-1 DNA binding activity and the MAPK pathway in MCF-7 cells (A and B) Cells were treated with sulfuretin in the presence of TPA, and nuclear extracts were prepared following a 4-h incubation. Nuclear factor (NF)- $\mathrm{\kappa B}$ and activating protein-1 (AP-1) DNA binding was analyzed by electrophoretic mobility shift assay (EMSA). (C) Cells were pretreated with TPA for 30 min in the presence or absence of sulfuretin. Cell lysates were prepared for western blotting with specific p-p38, p38, p-JNK, JNK, p-ERK and ERK antibodies. (D and E) Western blotting was performed to determine the nuclear levels of NF-kB (p50 and p65) and AP-1 (p-c-Jun) subunits as well as the cytoplasmic

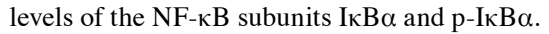

that sulfuretin blocked TPA-induced MMP-9 upregulation in a dose-dependent manner (Fig. 2B). A zymography analysis was carried out to determine the effect of sulfuretin on TPA-induced MMP-9 secretion. The analysis demonstrated that treatment of MCF-7 cells with TPA increased MMP-9 secretion, while sulfuretin significantly diminished the TPA-induced MMP-9 secretion (Fig. 2C). These results were consistent with the potent sulfuretin-mediated inhibition of TPA-induced MMP-9 expression in MCF-7 cells.

Sulfuretin inhibits TPA-induced NF- $\kappa B$ DNA binding activity but not the AP-1 and MAPK pathway. To clarify the mechanism involved in the sulfuretin-mediated inhibition of MMP-9 expression, the effects of sulfuretin on TPA-induced activation of NF- $\mathrm{NB}$ and AP-1 were evaluated using EMSA. As shown in Fig. 3A and B, TPA substantially increased NF- $\kappa$ B and AP-1 binding activity. Pretreatment with sulfuretin inhibited TPA-stimulated NF- $\mathrm{BB}$ binding activity but not that of AP-1. These results were consistent with the view that sulfuretin specifically blocks NF- $\mathrm{B}$ activation in MCF-7 cells. In the western blot analysis, TPA stimulated the phosphorylation of $\mathrm{IKK} \alpha \beta$ and I $\mathrm{I} \mathrm{B} \alpha$ in the cytoplasm and, thereby, the nuclear translocation of $\mathrm{NF}-\kappa \mathrm{B}$ subunits $\mathrm{p} 50$ and p65. In the case of AP-1, c-Jun expression was considerably augmented, while c-Fos expression was only negligibly induced in the TPA-treated cells. Based on our results, the increased p-IKK $\alpha \beta, \mathrm{p}-\mathrm{I} \kappa \mathrm{B} \alpha$ and translocation of p65 and p50 as a result of TPA stimulation was significantly suppressed by sulfuretin treatment (Fig. 3D and E). We confirmed that TPA induced the phosphorylation of c-Jun, a major subunit of AP-1, and sulfuretin had no effect on c-Jun phosphorylation (Fig. 3E). The effect of sulfuretin on TPA-induced phosphorylation and activation of MAPKs was investigated to determine the inhibitory effect of sulfuretin on MAPK. Sulfuretin had no effect on MAPK phosphorylation 30 min after TPA treatment (Fig. 3C). These results suggest that the regulation of TPA-induced MMP-9 expression by sulfuretin does not involve the MAPK pathway.

Effect of sulfuretin on TPA-induced MCF-7 cell invasion in vitro. Upregulation of MMP-9 expression contributes to 

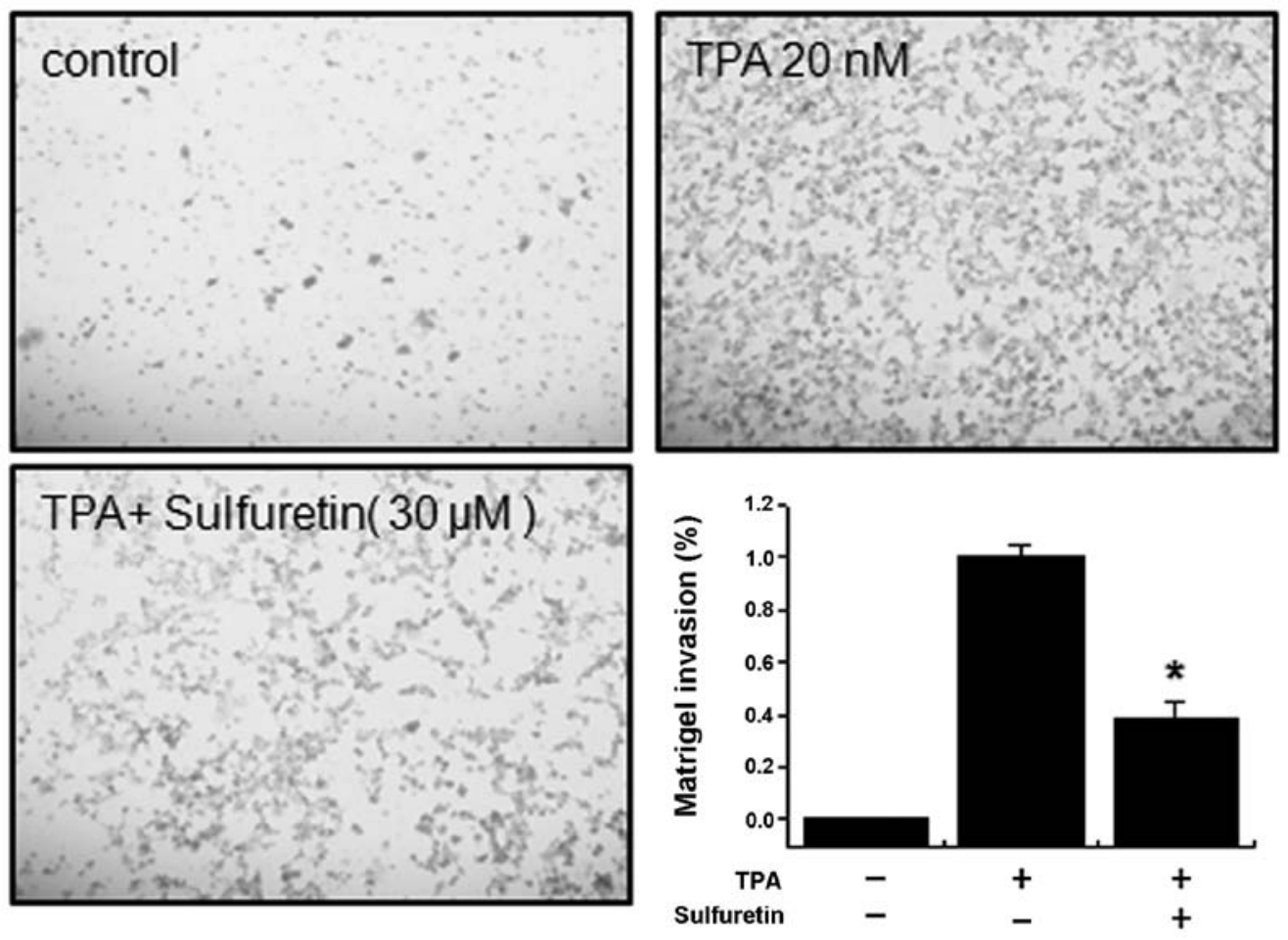

Figure 4. Effect of sulfuretin on TPA-induced Matrigel invasion in MCF-7 cells. Cells were seeded onto the upper chamber, and drugs were placed in the well. After a 24-h incubation, cells on the bottom of the filter were fixed, stained and counted. Each value represents the mean \pm standard error of three independent experiments. ${ }^{*} \mathrm{p}<0.01$ vs. TPA.

the increased invasiveness of cancer cells $(25,26)$. An in vitro invasion assay was used to investigate the inhibitory effects of sulfuretin on the invasive ability of MCF-7 cells. Treatment with TPA increased MCF-7 cell invasion when compared with that in untreated control cells, as determined by a Matrigel invasion assay. Incubating MCF-7 cells with TPA resulted in a 10 -fold increase in cell invasiveness. However, treatment with sulfuretin diminished TPA-induced cell invasion by $65 \%$ (Fig. 4).

\section{Discussion}

Studies involved in the development of effective anti-invasive strategies have focused mainly on the utilization of natural bioactive agents in MCF-7 cells. In the present study, we isolated sulfuretin from the heartwood of Rhus verniciflua Stokes (RVS) and examined its effects on TPA-induced MMP-9 expression and cellular invasion in MCF-7 cells. RVS exerts a remarkable spectrum of biological activities affecting basic cellular functions, and the identification of sulfuretin as an active principle agent has been demonstrated $(19,22,23,27-34)$. In previous reports, sulfuretin exerted anticancer and antiproliferative effects in various types of cells $(28,30)$. Additionally and consistent with these results, our previous observations indicated that sulfuretin inhibits MMP expression and inflammatory responses by interfering with the transcriptional activation of NF- $\kappa \mathrm{B}(23,27,35)$. However, no study has reported on the anti-invasive effects of sulfuretin in MCF-7 cells. Thus, we designed this study to estimate the anti-invasive potential of sulfuretin and to explore the molecular mechanisms underlying its activity.
Metastasis is the primary cause of breast cancer mortality. Tumor metastasis is a multistep process by which a subset of individual cancer cells disseminates from a primary tumor to distant secondary organs or tissues. This process involves cell proliferation, ECM degradation, cell migration and tumor growth at metastatic sites $(10,36)$. Tumor cell invasion is an early step in the metastatic cascade, representing the beginning of the transition from the benign stage to malignancy. Tumor invasion is morphologically associated with a distorted edge of the primary tumor where individual or cohorts of tumor cells actively invade the ECM surrounding the primary tumor (37). MMP-9 has been regarded as a major critical molecule during tumor invasion and metastasis. MMP-9 activation is particularly associated with tumor progression and invasion, including that in mammary tumors (38). Inflammatory cytokines, growth factors and phorbol esters stimulate MMP-9 by activating different intracellular-signaling pathways in breast cancer cells (39-41). The inhibitory effect on MMP-9 expression is important for developing a therapeutic experimental model of tumor metastasis.

$\mathrm{NF}-\kappa \mathrm{B}$ and AP-1 are transcription factors important in regulating MMP-9, as the MMP-9 gene promoter contains $\mathrm{NF}-\kappa \mathrm{B}$ and AP-1 binding sites (15). AP-1, which belongs to the bZIP group of DNA-binding proteins, associates to form a variety of homodimers and heterodimers through a combination of signaling events, leading to increased activity of proteins that directly potentiate Jun and Fos family members or activate transcription factors that regulate c-jun and c-fos expression (42-45). NF- $\kappa \mathrm{B}$ comprises a family of inducible transcription factors that regulate host inflammatory and immune responses (46). Diverse signal transduction cascades 


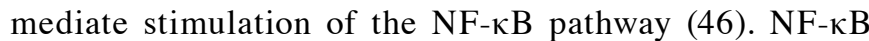
and AP-1 elements are centrally involved in TPA-mediated MMP-9 gene induction $(36,47)$. Additionally, the MAPK signaling pathway is important for NF- $\mathrm{KB}$ activation, which requires I- $\kappa \mathrm{B}$ kinase depending on cell type $(14,16-18,48)$. However, our results showed that sulfuretin inhibited activation of NF-kB but not MAPK or AP-1 in MCF-7 cells. This result suggests that sulfuretin inhibited TPA-induced MMP-9 expression through the NF- $\mathrm{KB}$ pathway.

These experiments confirmed that TPA-stimulated cell invasion was suppressed by sulfuretin. Data obtained from the Matrigel invasion assay showed that sulfuretin inhibited the TPA-induced invasive potential of MCF-7 cells (Fig. 4). These data suggest that the inhibition cell invasion caused by sulfuretin was correlated with inhibition of MMP-9 expression and the NF- $\mathrm{kB}$ signaling pathway.

In conclusion, our results demonstrated that sulfuretin is a potent inhibitor of TPA-induced MMP-9 expression, and that it strongly blocked the NF- $\mathrm{KB}$ signaling pathway in breast carcinoma cells. This is the first study to show that sulfuretin suppresses TPA-stimulated cancer cell invasion by inhibiting MMP-9 expression. We also detailed the molecular mechanisms of the NF- $\mathrm{KB}$ pathway in breast cancer cells responsible for this inhibitory effect. Thus, sulfuretin may be a potential candidate for preventing breast tumor invasion and metastasis in vivo.

\section{Acknowledgements}

This study was supported by a National Research Foundation of Korea (NRF) grant funded by the Korea Government (MEST) (no. 2011-0030716), Republic of Korea.

\section{References}

1. Jemal A, Murray T, Ward E, et al: Cancer statistics, 2005. CA Cancer J Clin 55: 10-30, 2005.

2. Friedel G, Pastorino U, Ginsberg RJ, et al: Results of lung metastasectomy from breast cancer: prognostic criteria on the basis of 467 cases of the International Registry of Lung Metastases. Eur J Cardiothorac Surg 22: 335-344, 2002.

3. Woessner JF Jr: Matrix metalloproteinases and their inhibitors in connective tissue remodeling. FASEB J 5: 2145-2154, 1991

4. Nakajima M, Welch DR, Belloni PN and Nicolson GL: Degradation of basement membrane type IV collagen and lung subendothelial matrix by rat mammary adenocarcinoma cell clones of differing metastatic potentials. Cancer Res 47 4869-4876, 1987.

5. Egeblad M and Werb Z: New functions for the matrix metalloproteinases in cancer progression. Nat Rev Cancer 2: 161-174, 2002.

6. Saito N, Hatori T, Murata N, et al: A double three-step theory of brain metastasis in mice: the role of the pia mater and matrix metalloproteinases. Neuropathol Appl Neurobiol 33: 288-298, 2007.

7. Castellano G, Malaponte G, Mazzarino MC, et al: Activation of the osteopontin/matrix metalloproteinase-9 pathway correlates with prostate cancer progression. Clin Cancer Res 14: 7470-7480, 2008 .

8. Kanayama H: Matrix metalloproteinases and bladder cancer. J Med Invest 48: 31-43, 2001.

9. Lin CW, Hou WC, Shen SC, et al: Quercetin inhibition of tumor invasion via suppressing PKC delta/ERK/AP-1-dependent matrix metalloproteinase-9 activation in breast carcinoma cells. Carcinogenesis 29: 1807-1815, 2008.

10. Lee SO, Jeong YJ, Kim M, Kim CH and Lee IS: Suppression of PMA-induced tumor cell invasion by capillarisin via the inhibition of NF-kappaB-dependent MMP-9 expression. Biochem Biophys Res Commun 366: 1019-1024, 2008.
11. Newton AC: Regulation of protein kinase C. Curr Opin Cell Biol 9: 161-167, 1997.

12. Zeigler ME, Chi Y, Schmidt T and Varani J: Role of ERK and JNK pathways in regulating cell motility and matrix metalloproteinase 9 production in growth factor-stimulated human epidermal keratinocytes. J Cell Physiol 180: 271-284, 1999.

13. Hozumi A, Nishimura Y, Nishiuma T, Kotani Y and Yokoyama M: Induction of MMP-9 in normal human bronchial epithelial cells by TNF-alpha via NF-kappa B-mediated pathway. Am J Physiol Lung Cell Mol Physiol 281: L1444-L1452, 2001.

14. Weng CJ, Chau CF, Hsieh YS, Yang SF and Yen GC: Lucidenic acid inhibits PMA-induced invasion of human hepatoma cells through inactivating MAPK/ERK signal transduction pathway and reducing binding activities of NF-kappaB and AP-1. Carcinogenesis 29: 147-156, 2008.

15. Eberhardt W, Huwiler A, Beck KF, Walpen S and Pfeilschifter J: Amplification of IL-1 beta-induced matrix metalloproteinase-9 expression by superoxide in rat glomerular mesangial cells is mediated by increased activities of NF-kappa B and activating protein-1 and involves activation of the mitogen-activated protein kinase pathways. J Immunol 165: 5788-5797, 2000.

16. Yao J, Xiong S, Klos K, et al: Multiple signaling pathways involved in activation of matrix metalloproteinase-9 (MMP-9) by heregulin-betal in human breast cancer cells. Oncogene 20: 8066-8074, 2001.

17. Karin M: The regulation of AP-1 activity by mitogen-activated protein kinases. J Biol Chem 270: 16483-16486, 1995.

18. Madrid LV, Mayo MW, Reuther JY and Baldwin AS Jr: Akt stimulates the transactivation potential of the RelA/p65 subunit of NF-kappaB through utilization of the IkappaB kinase and activation of the mitogen-activated protein kinase p38. J Biol Chem 276: 18934-18940, 2001.

19. Lee JC, Lim KT and Jang YS: Identification of Rhus verniciflua Stokes compounds that exhibit free radical scavenging and antiapoptotic properties. Biochim Biophys Acta 1570: 181-191, 2002.

20. Jeon WK, Lee JH, Kim HK, et al: Anti-platelet effects of bioactive compounds isolated from the bark of Rhus verniciflua Stokes. J Ethnopharmacol 106: 62-69, 2006.

21. Jung CH, Kim JH, Hong MH, et al: Phenolic-rich fraction from Rhus verniciflua Stokes (RVS) suppress inflammatory response via NF-kappaB and JNK pathway in lipopolysaccharide-induced RAW 264.7 macrophages. J Ethnopharmacol 110: 490-497, 2007.

22. Park KY, Jung GO,Lee KT, et al: Antimutagenic activity of flavonoids from the heartwood of Rhus verniciflua. J Ethnopharmacol 90: 73-79, 2004.

23. Song MY, Jeong GS, Kwon KB, et al: Sulfuretin protects against cytokine-induced beta-cell damage and prevents streptozotocininduced diabetes. Exp Mol Med 42: 628-638, 2010.

24. Bradford MM: A rapid and sensitive method for the quantitation of microgram quantities of protein utilizing the principle of protein-dye binding. Anal Biochem 72: 248-254, 1976.

25. Chambers AF and Matrisian LM: Changing views of the role of matrix metalloproteinases in metastasis. J Natl Cancer Inst 89: 1260-1270, 1997.

26. Stetler-Stevenson WG, Hewitt R and Corcoran M: Matrix metalloproteinases and tumor invasion: from correlation and causality to the clinic. Semin Cancer Biol 7: 147-154, 1996.

27. Song MY, Jeong GS, Lee HS, et al: Sulfuretin attenuates allergic airway inflammation in mice. Biochem Biophys Res Commun 400: 83-88, 2010.

28. Jang HS, Kook SH, Son YO, et al: Flavonoids purified from Rhus verniciflua Stokes actively inhibit cell growth and induce apoptosis in human osteosarcoma cells. Biochim Biophys Acta 1726: 309-316, 2005.

29. Jang DS, Park EJ, Hawthorne ME, et al: Potential cancer chemopreventive constituents of the seeds of Dipteryx odorata (tonka bean). J Nat Prod 66: 583-587, 2003.

30. Lee JC, Lee KY, Kim J, et al: Extract from Rhus verniciflua Stokes is capable of inhibiting the growth of human lymphoma cells. Food Chem Toxicol 42: 1383-1388, 2004.

31. Son YO, Lee KY, Lee JC, et al: Selective antiproliferative and apoptotic effects of flavonoids purified from Rhus verniciflua Stokes on normal versus transformed hepatic cell lines. Toxicol Lett 155: 115-125, 2005

32. Ko JH, Lee SJ and Lim KT: $36 \mathrm{kDa}$ glycoprotein isolated from Rhus verniciflua Stokes fruit has a protective activity to glucose/ glucose oxidase-induced apoptosis in NIH/3T3 cells. Toxicol In Vitro 19: 353-363, 2005.

33. Lim KT, Hu C and Kitts DD: Antioxidant activity of a Rhus verniciflua Stokes ethanol extract. Food Chem Toxicol 39: 229-237, 2001. 
34. Choi J, Yoon BJ, Han YN, et al: Antirheumatoid arthritis effect of Rhus verniciflua and of the active component, sulfuretin. Planta Med 69: 899-904, 2003.

35. Lee YR, Hwang JK, Koh HW, et al: Sulfuretin, a major flavonoid isolated from Rhus verniciflua, ameliorates experimental arthritis in mice. Life Sci 90: 799-807, 2012.

36. Chung TW, Moon SK, Chang YC, et al: Novel and therapeutic effect of caffeic acid and caffeic acid phenyl ester on hepatocarcinoma cells: complete regression of hepatoma growth and metastasis by dual mechanism. FASEB J 18: 1670-1681, 2004.

37. Deryugina EI and Quigley JP: Matrix metalloproteinases and tumor metastasis. Cancer Metastasis Rev 25: 9-34, 2006.

38. Scorilas A, Karameris A, Arnogiannaki N, et al: Overexpression of matrix-metalloproteinase-9 in human breast cancer: a potential favourable indicator in node-negative patients. Br J Cancer 84 1488-1496, 2001.

39. Cho HJ, Kang JH, Kwak JY, et al: Ascofuranone suppresses PMA-mediated matrix metalloproteinase-9 gene activation through the Ras/Raf/MEK/ERK- and Ap1-dependent mechanisms. Carcinogenesis 28: 1104-1110, 2007.

40. Kajanne R, Miettinen P, Mehlem A, et al: EGF-R regulates MMP function in fibroblasts through MAPK and AP-1 pathways. J Cell Physiol 212: 489-497, 2007.

41. Srivastava AK, Qin X, Wedhas N, et al: Tumor necrosis factor-alpha augments matrix metalloproteinase-9 production in skeletal muscle cells through the activation of transforming growth factor-beta-activated kinase 1 (TAK1)-dependent signaling pathway. J Biol Chem 282: 35113-35124, 2007.
42. Frigo DE, Tang Y, Beckman BS, et al: Mechanism of AP-1mediated gene expression by select organochlorines through the p38 MAPK pathway. Carcinogenesis 25: 249-261, 2004

43. Shaulian E and Karin M: AP-1 in cell proliferation and survival. Oncogene 20: 2390-2400, 2001.

44. Yokoo T and Kitamura M: Dual regulation of IL-1 beta-mediated matrix metalloproteinase-9 expression in mesangial cells by NF-kappa B and AP-1. Am J Physiol 270: F123-F130, 1996.

45. Lungu G, Covaleda L, Mendes O, Martini-Stoica H and Stoica G FGF-1-induced matrix metalloproteinase- 9 expression in breast cancer cells is mediated by increased activities of NF-kappaB and activating protein-1. Mol Carcinog 47: 424-435, 2008.

46. Yamamoto Y and Gaynor RB: Therapeutic potential of inhibition of the NF-kappaB pathway in the treatment of inflammation and cancer. J Clin Invest 107: 135-142, 2001.

47. Hong S, Park KK, Magae J, et al: Ascochlorin inhibits matrix metalloproteinase-9 expression by suppressing activator protein-1-mediated gene expression through the ERK1/2 signaling pathway: inhibitory effects of ascochlorin on the invasion of renal carcinoma cells. J Biol Chem 280: 25202-25209, 2005.

48. Ruhul Amin AR, Senga T, Oo ML, Thant AA and Hamaguchi M: Secretion of matrix metalloproteinase- 9 by the proinflammatory cytokine, IL-1beta: a role for the dual signalling pathways, Akt and Erk. Genes Cells 8: 515-523, 2003. 